\title{
Interest Rate Reforms And Credit Allocation In Tanzania: An Application Of The ARDL Bounds Testing Approach
}

Nicholas M. Odhiambo, University of South Africa, South Africa

\begin{abstract}
This study attempts to empirically investigate the impact of interest rate reforms on the efficiency of credit allocation in Tanzania, using the recently developed ARDL-Bounds test approach proposed by Pesaran et al. (2001). Contrary to the results obtained in some previous studies, the current study finds a distinct positive relationship between interest rate and investment efficiency in Tanzania. The coefficient of real interest rate in the investment efficiency function is found to be positive and statistically significant, as expected. The study, therefore, concludes that the financial system in Tanzania has had a significant and positive influence on the quality of investment during the study period. It also implies that the current financial liberalisation taking place in Tanzania has succeeded in transferring capital from projects with low returns to projects with high returns. However, this applies only in the short-run.
\end{abstract}

Keywords: Africa, Tanzania, Interest Rate Reforms, Investment Efficiency

\section{INTRODUCTION}

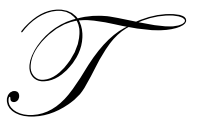

anzania, like many other developing countries, has implemented a number of reforms since the widespread acceptance of the ideal of financial liberalisation. Although Tanzania started pursuing financial reforms as early as the 1980s, it was only in the 1990s that fully-fledged financial reforms were implemented. This was because the country wanted to avoid a rapid or 'big bang' financial liberalisation situation (Odhiambo, 2004). Moreover, it was necessary for the country to attain some level of macroeconomic stability before fully liberalising its financial sector. For example, it was only in 1992 that the Bank of Tanzania (BOT) lifted its responsibility of setting interest rates (except for the maximum lending rate). In the same year, the Foreign Exchange Act 1992 was passed and replaced the Exchange Control Ordinance. In 1993, the lending interest rate ceiling of $31 \%$ was abolished and the 91 -day Treasury bill auction commenced. During the same year, a number of foreign exchange reforms were undertaken. A bureau de change market was introduced in April 1993, in an effort toward foreign exchange liberalisation, and, in July 1993, BOT began auctioning foreign exchange. This had a joint effect of liquidity management and market-based exchange rate determination. In August 1993, bureaus and official exchange rates were unified and, thereafter, forex auctions were extended to include commercial banks. In 1994 the requirement of a positive real deposit rate was abolished. A year later, the liquidity asset ratio was also abolished, and in 1996, the credit ceiling on commercial banks' lending was also abolished ${ }^{1}$.

Unfortunately, the implementation of the financial liberalisation policy in Tanzania, just as in many other developing countries, resulted in a number of challenges. These include high interest rates, a wide and expanding spread between lending and deposit rates, a systematic decline in domestic credit to the private sector, an unstable exchange rate and mixed trends in financial depth. For example, since the liberalisation of interest rates in 1994, the spread between the lending and deposit rates has widened significantly. The general trend of domestic credit to the private sector has also declined dramatically from $28.62 \%$ in 1991 to $6.98 \%$ in 1998. Although savings and investment have shown positive trends since 1998, the pre-reform average savings and investment levels generally exceed the post-reform levels.

\footnotetext{
${ }^{1}$ For more details, see Odhiambo (2004).
} 
The aim of the current study, therefore, is to examine the impact of interest rate reforms on the quality of credit allocation in Tanzania during the period 1975-2005 - using the recently developed ARDL-Bounds test approach. The study seeks to answer one critical question: Does interest rate liberalisation have any positive influence on the efficient allocation of credit in Tanzania? The remainder of the paper is organised as follows: The next section sketches the underlying theory of financial liberalisation and how it impacts on the quality of investment. The third section traces the trends of credit allocation in Tanzania before and after financial liberalisation. An Empirical model of investment efficiency and the associated estimation techniques are presented in section 4 . The final section summarises and concludes the study.

\section{LITERATURE REVIEW}

The theoretical relationship between financial liberalisation and investment efficiency is based on the theoretical underpinning of McKinnon's (1973) thesis. McKinnon (1973) in his influential book titled "Money and Capital in Economic Development", combined both the theoretical analysis and an illustration of the malfunctioning of capital markets in developing countries. The essential message here is that, at low real interest rates, people would not want to hold much money or other financial assets. As a result, the financial system would not adequately be able to fulfil one of its primary functions of integrating capital and capital markets and equalising returns to investment (see Thornton, 1990). According to McKinnon, the demand for money changes as households and firms shift from consumption to investment because investment is lumpier and requires a longer period of accumulation from a given income stream before disbursement. Therefore, his proposition is that a rise in the rate of interest increases the volume of financial savings through financial intermediaries and thereby raises investment funds, a phenomenon he called the "conduit effect". The realised investment in this case will increase because of the greater availability of funds. McKinnon further rationalised his complementarity relationship between investment, real assets and real money balances by stating that an increase in real money balances would mean greater efficiency and, therefore, would raise output sufficiently to offset the declining share of output allocated to investment (McKinnon, 1973: 46; Khatkhate, 1988). Hence, higher positive real interest rates are warranted to build up real money balances, increase financial intermediation and unification of financial markets, thereby ensuring an efficient utilisation of resources, particularly the scarce capital. The complementarity between money and capital accumulation will, therefore, continue to exist as long as the real positive interest rate does not exceed the real rate of return on investment.

One question which has recently emerged from the literature is whether the mechanism through which financial liberalisation affects economic growth is based on the efficiency or volume of investment. Theoretical studies such as Greenwood and Jovanovic (1990), Bencivenga and Smith (1991), Renelt and Levine (1992), and Saint-Paul (1992) present models in which the gains from increased financial development stem from increased efficiency in the allocation of investment rather than from a larger volume of investment. De Gregorio and Guidotti (1995) also estimate that some $75 \%$ of the positive correlation between financial intermediation and growth is due to increased investment efficiency, rather than an increased volume of investment. Gelb (1989) finds that most of the positive association between real interest rates and growth stemmed from the efficiency effect rather than the level of investment. Cho (1988) argues that financial reform has led to an increase in allocative efficiency of investment because the cost of borrowing in different sectors and industries has narrowed sharply since 1980. The author argues that, abstracting from risk and uncertainty, an economy can be said to allocate capital efficiently if the marginal return on investment across sectors is equalised.

On the empirical front, a number of studies have been conducted in developing countries in order to examine the relationship between financial liberalisation and investment efficiency - but with conflicting results. Nyagetera (1997), for example, while conducting a study on the financial repression in Tanzania and its impact on savings, investment, credit and growth, concludes that, on the one hand, an increase in real lending rate tends to raise the firms' operating costs and lowers their profitability, which in turn lowers their investment efficiency or productivity. On the other hand, an increase in real deposit rate may have a positive influence on investment efficiency if it increases the supply of financial savings and real credit availability from the financial system, which facilitates capacity utilisation of existing investments and in the process improves firms' profitability and capital productivity (see Nyagetera, 1997: 342-343). The gains in investment efficiency after financial liberalization have also been documented in a number of individual countries' studies using firm level data. In the case of Ecuador, 
Jaramillo et al. (1992) found that, after controlling for firms' other characteristics, there was an increase in the flow of credit to more technologically-efficient firms after financial liberalisation. Specifically, the author found that the flow of credit moved from smaller to larger firms after liberalisation. This shows that the small-scale firms had been subsidised during the period prior to reform in Ecuador. The shift in credit toward large firms was, therefore, a case in which credit shifted to the area that had been discriminated against under the system of financial repression. In Indonesia, Siregar (1992) and Harris et al (1992) find that after liberalization more technologically-efficient firms received a greater proportion of new $\mathrm{credit}^{2}$. In Argentina, Morisset (1993) finds that although the effect of financial liberalisation on the quantity of investment was weak (and even negative in some tests), the effect on the quality of investment was consistently positive.

Although the bulk of the evidence seems to argue that financial liberalisation has contributed somewhat towards more efficient credit allocation, this argument is not unanimous. De Gregorio (1992), for instance, argues that credit to the private sector was negatively related to growth in the 1970s and 1980s in Latin America. The author attributes this negative correlation to inefficient lending by banks in the light of poor regulatory incentives. Capoglu (1990), while examining the effect of reforms in Turkey, which began in 1980, found that the reforms had made very little difference to the functional efficiency of the financial sector (as measured by the spread between lending and deposit rates). The author argues that even when Cho's (1988) method of assessing the quality of investment was used, there was still no evidence that financial reforms in Turkey had led to a rise in investment efficiency.

\section{FINANCIAL LIBERALISATION AND CREDIT ALLOCATION IN TANZANIA}

Although one of the main aims of financial liberalisation in Tanzania was to increase the allocation of credit to the private sector, this did not materialise after the liberalisation of the financial sector in the 1990s. Instead, credit allocated to the private sector steadily declined. Indeed, the performance of credit growth, particularly credit available to Tanzania's productive sectors, has not been impressive since the liberalisation of the financial sector in the 1990s (see Ziorklui, 2001) ${ }^{3}$. For example, the credit expansion to the private sector as a percentage of GDP declined from $28.62 \%$ in 1991 to $6.98 \%$ in 1998. Likewise, the total credit allocation as a percentage of the aggregate deposit dropped from $154 \%$ in 1991 to about $28.45 \%$ in 1998. Although the declining trend of the credit to the private sector in Tanzania has cast doubts on the efficacy of financial liberalisation towards extending credit to the Tanzanian private sector, this can be largely attributed to the banking sector's collapse before the initiation of financial sector reforms. Since the banking sector provides the link between short-term and long-term credit to the private sector through loans and overdraft advances, the collapse of the banking sector had a deleterious effect on credit allocation to the private sector. Also, the history of loan defaults affected the general modality of extending long-term credit to the private sector. The Bank of Tanzania's implementation of its prudential regulatory and supervisory functions also significantly contributed to the decline in credit allocation to the private sector. The bank's imposition of lending restrictions on problem borrowers resulted in a sharp decline to parastatal enterprises, most of which had large non-performing loans. The restructuring of the National Bank of Commerce (NBC), the largest bank in the country, also had an impact on credit allocation to the private sector (Ziorklui, 2001). Although it was expected that the restructuring of NBC into corporate and microfinance divisions would benefit small and medium-sized enterprises in terms of their credit needs, this did not materialise as the NBC maintained a stringent loan portfolio management during its restructuring, which resulted in a drastic decline of credit to the private sector. Moreover, the expectation that the banks' restructuring would lead to an increase in credit allocation was further dampened by the lack of competition among commercial banks and the attractiveness of government Treasury Bills. Another overriding factor that could have inhibited banks from extending credit to the private sector is the increase in statutory reserve requirements by BOT. The minimum reserve ratio, for example, was increased from $12 \%$ in 1994 to $18 \%$ in 1995 - although the ratio was later reduced to $12 \%$ and 10\% in 1996 and 1997 respectively [For more details, see Ziorklui (2001)]. This decline in credit allocation to the private sector, amongst other factors, led to a mixed trend in investment in Tanzania - following the liberalisation of the financial sector in the 1990s. For example, the investment ratio as a percentage of GDP decreased from $27.2 \%$ in 1992 to $24.6 \%$ in $1994,16.6 \%$ in 1996 and to $13.5 \%$ in 1998. However, since 1999 there has been a significant improvement in investment in

\footnotetext{
${ }^{2}$ For more details, see Caprio et al. (1994) and Williamson and Mohar (1998).

${ }^{3}$ See also Odhiambo (2004).
} 
Tanzania. For example, gross domestic investment increased from $13.5 \%$ in 1998 to $15.9 \%$ and $17.7 \%$ in 1999 and 2000 respectively.

\section{EMPIRICAL MODEL SPECIFICATION}

\subsection{Investment Efficiency Equation}

In this section, the hypothesis, which states that a rise in real interest rates increases the average efficiency of investment (incremental output capital ratio), is tested. The incremental output capital ratio (IOCR) is regressed on the real deposit rate of interest ( $\left.\mathrm{d}-\mathrm{P}^{\mathrm{e}}\right)$, real exchange rate and foreign savings. The real exchange rate variable has been included in the investment efficiency equation because depreciation of real exchange is expected to improve capacity utilisation of existing investment, which improves firm profitability, and hence efficiency of investment. The coefficient of the real exchange rate is, therefore, expected to be positive. Foreign savings rate on the other hand is expected to ease the foreign exchange constraint, thereby facilitating the fuller utilisation of existing capital equipment. Consequently, its coefficient is expected to be positive (see also Nyagetera, 1997). The investment efficiency (IOCR) equation is, therefore, presented as follows (see also Odhiambo, 2003):

$$
\mathrm{IOCR}=\mathrm{f}\left(\mathrm{D}-\mathrm{P}^{\mathrm{e}}, \mathrm{Sf} / \mathrm{Y}, \mathrm{Rexr}, \mathrm{e}_{\mathrm{t}}\right)
$$

The above model can be specified as:

$$
I O C R=\psi_{0}+\psi_{1}(d-P e)+\psi_{2} S f / Y+\psi_{3} \log \operatorname{Re} x r+\varepsilon_{t}
$$

Where: $\mathrm{d}-\mathrm{Pe}=$ real deposit rate of interest; $\mathrm{Sf} / \mathrm{Y}=$ foreign savings ratio; $\mathrm{Rexr}=$ real exchange rate; $\varepsilon_{\mathrm{t}}=$ error term. The evidence of investment efficiency will be achieved if;

$$
\delta(\mathrm{IOCR}) / \delta(\mathrm{d}-\mathrm{Pe})>0 \text {. }
$$

The expected signs of other variables are as follows;

$$
\begin{aligned}
& \delta(\mathrm{IOCR}) / \delta(\mathrm{Sf} / \mathrm{Y})>0 \\
& \delta(\mathrm{IOCR}) / \delta(\mathrm{Rexr})>0
\end{aligned}
$$

The investment efficiency model specified in equation (1) is adopted from Nyagetera (1997) and is similar to that used by Ikhide (1992), except that in this case variables such as real exchange rate and foreign savings rate have been included as determinants of incremental output capital ratio.

\subsection{Data Source And Definitions Of Variables}

\subsubsection{Data Source}

This study utilises annual time series data, which covers the 1975 and 2006 period. The data used in the study are obtained from different sources, which include; various series of Bank of Tanzania Bulletin and International Financial Statistics Year Books.

\subsubsection{Definitions of Variables}

- $\quad$ Foreign savings is measured by the current account deficit in the balance of payment account;

- Incremental output capital ratio (IOCR) is estimated as: $I O C R=y / / / Y$ - where; $y$ is the growth rate in real income and $\mathrm{I} / \mathrm{Y}$ is gross domestic investment as a ratio of GDP; 
- $\quad$ The real exchange rate is computed as: $\operatorname{Rexr}=\operatorname{NExr} * C P I(U S) / C P I(T Z)$ - where Rexr $=$ Real exchange rate, $N E x r=$ Nominal exchange rate, $C P I(U S)=$ consumer price index of United States of America, and $C P I(T Z)=$ Consumer price index of Tanzania;

- $\quad$ Real interest rate is computed as a residual of nominal deposit rate less expected inflation - where the unobservable expected rate of inflation is generated from the actual inflation rate.

\subsection{Estimation Techniques and Empirical Results}

\subsubsection{Unit-Root Tests}

Table 1: Stationarity Tests of Variables on first Difference - Phillips-Perron (PP) Test

\begin{tabular}{|c|c|c|c|}
\hline Variable & NO TREND & TREND & Stationarity Status \\
\hline \multicolumn{4}{|c|}{ Phillips-Perron (PP) } \\
\hline DIOCR & $-7.25507 * * *$ & $-7.01293 * * *$ & Stationary \\
\hline Dd-Pe & $-9.0097 * * *$ & $-11.9794 * * *$ & Stationary \\
\hline DRexr & $-3.343395 * * *$ & $-3.27896 * *$ & Stationary \\
\hline DFS & $-4.83275 * * *$ & $-4.82406 * * *$ & Stationary \\
\hline
\end{tabular}

Note: 1)The truncation lag for the PP tests is based on Newey and West (1987) bandwidth.

2 ) $* * *, * *$, and $*$ denote $1 \%, 5 \%$ and $10 \%$ level of significance, respectively.

Table 2: Stationarity Tests of Variables on first Difference - Dickey-Fuller - GLS Test

\begin{tabular}{|c|c|c|c|}
\hline Variable & NO TREND & TREND & Stationarity Status \\
\hline DIOCR & $-7.23629 * * *$ & $-7.095098^{* * *}$ & Stationary \\
\hline Dd-Pe & $-8.28859 * * *$ & $-8.48164 * * *$ & Stationary \\
\hline DRexr & $-3.34953 * * *$ & $-3.36468 * *$ & Stationary \\
\hline DFS & $-4.95064 * * *$ & $-4.97052 * * *$ & Stationary \\
\hline
\end{tabular}

Note: 1) Critical values for Dickey-Fuller GLS test are based on Elliot-Rothenberg-Stock (1996, Table 1).

$2) * * *, * *$, and $*$ denote $1 \%, 5 \%$ and $10 \%$ level of significance, respectively.

Table 3: Stationarity Tests of Variables on first Difference - Ng -Perron TEST

\begin{tabular}{|c|c|c|c|c|c|}
\hline Variable & \multicolumn{4}{|c|}{ Ng-Perron Test Statistics (without Trend) } & Stationarity Status \\
\hline & $\mathrm{MZ}$ & $\mathrm{MZt}$ & MSB & MPT & Stationary \\
\hline DIOCR & -62.5966 & -5.52631 & 0.08828 & 0.54689 & Stationary \\
\hline Dd-Pe & -16.5585 & -2.87737 & -0.17377 & 1.47960 & Stationary \\
\hline DRexr & -34.2665 & -4.13903 & -0.12079 & 0.71557 & Stationary \\
\hline DFS & -17.9099 & -2.99236 & 0.16708 & 1.36838 & Stationary \\
\hline \multicolumn{6}{|c|}{ Asymptotic Critical Values - (Ng -Perron, 2001, Table 1) } \\
\hline $1 \%$ & -13.8000 & -2.5800 & 0.17400 & 1.7800 & \\
\hline $5 \%$ & -8.1000 & -1.9800 & 0.23300 & 3.1700 & \\
\hline $10 \%$ & -5.7000 & -1.6200 & 0.27500 & 4.4500 & \\
\hline Variable & \multicolumn{4}{|c|}{ Ng-Perron Test Statistics (with Trend) } & Stationarity Status \\
\hline & $\mathrm{MZ}$ & $\mathrm{MZt}$ & MSB & MPT & \\
\hline DIOCR & -57.2260 & -5.29918 & 0.09260 & 1.82495 & Stationary \\
\hline Dd-Pe & -16.2364 & -2.84839 & 0.1754 & 6.61751 & Stationary \\
\hline DRexr & -34.4203 & -4.14850 & 0.12053 & 2.64746 & Stationary \\
\hline DFS & -17.9494 & -2.99486 & 0.16685 & 5.08232 & Stationary \\
\hline \multicolumn{6}{|c|}{ Asymptotic Critical Values - (Ng -Perron, 2001, Table 1) } \\
\hline $1 \%$ & -23.8000 & -3.42000 & 0.14300 & 4.03000 & \\
\hline $5 \%$ & -17.3000 & -2.91000 & 0.16800 & 5.48000 & \\
\hline $10 \%$ & -14.2000 & -2.62000 & 0.18500 & 6.67000 & \\
\hline
\end{tabular}

Although the ARDL modelling approach does not require unit root tests, it is important to conduct the unit root test in order to ensure that no variable is integrated of order 2 [I(2)] or higher. This is critical because the ARDL 
procedure assumes that all variables are either $\mathrm{I}(0)$ or $\mathrm{I}(1)$. If a variable is found to be $\mathrm{I}(2)$, then the computed Fstatistics produced by Pesaran et al (2001) are no longer valid. The most frequently used unit root test is based on the Augmented Dickey-Fuller test - a parametric approach originally proposed by Dickey and Fuller $(1979,1981)$. Unfortunately, it has been proved, using Monte Carlo simulations, that the power of the ADF test is very low. To overcome this problem, the semi-parametric Philips-Perron test proposed by Phillips and Perron (1988), the DickyFuller generalised least square de-trending (DF-GLS) test proposed by Elliot et al. (1996) and the newly developed $\mathrm{Ng}$-Perron test following $\mathrm{Ng}$ and Perron (2001) have been used in this study. The results of the stationarity tests at level (not presented here) show that all variables are non-stationary at level. Having found that the variables are not stationary at level, the next step is to difference the variables once in order to perform stationarity tests on differenced variables. The results of the stationarity tests on differenced variables are presented in Tables 1, 2 and 3.

The results reported in Tables 1, 2 and 3 show that after differencing the variables once, all the variables were confirmed to be stationary. The Phillips-Perron, DF-GLS and Ng-Perron tests applied to the first difference of the data series reject the null hypothesis of non-stationarity for all the variables used in this study. It is, therefore, worth concluding that all the variables are integrated of order one.

\subsubsection{The Autoregressive Distributed Lag (ARDL) Modelling Approach}

In this section the recently developed Autoregressive Distributed Lag (ARDL) - Bounds test approach is used to test the existence of a cointegration relationship between the IOCR and its regressors. The ARDL modelling approach was originally introduced by Perasan and Shin (1999) and later extended by Perasan et al. (2001). The ARDL cointegration approach has numerous advantages in comparison to other cointegration methods. Unlike other cointegration techniques, the ARDL does not impose a restrictive assumption that all the variables under study must be integrated of the same order. In other words, the ARDL approach can be applied regardless of whether the underlying regressors are integrated of order one [I(1)], order zero [I(0)] or fractionally integrated. Secondly, while other cointegration techniques are sensitive to the size of the sample, the ARDL test is suitable even if the sample size is small. Third, the ARDL technique generally provides unbiased estimates of the long-run model and valid tstatistics even when some of the regressors are endogenous (see also Harris and Sollis, 2003). The ARDL model used in this study can be expressed as follows:

\section{ARDL-Bounds Test}

$$
\begin{aligned}
& \Delta I O C R_{t}=\beta_{0}+\sum_{i=1}^{n} \beta_{1 i} \Delta I O C R_{t-i}+\sum_{i=0}^{n} \beta_{2 i} \Delta(d-P e)_{t-i}+\sum_{i=0}^{n} \beta_{3 i} \Delta S f_{t-i}+\sum_{i=0}^{n} \beta_{4 i} \Delta \operatorname{In} \operatorname{Re} x_{t-i} \\
& +\beta_{5} I O C R_{t-1}+\beta_{6}(d-P e)_{t-1}+\beta_{7} S f_{t-1}+\beta_{8} \operatorname{In} \operatorname{Re} x_{t-1}+\mu_{t}
\end{aligned}
$$

The first step in the ARDL modelling approach is to conduct the bounds test for equation 2. The bounds test involves performing the F-test on the null hypothesis of no cointegration (i.e. Ho: $\pi_{1}=\pi_{2}=\pi_{3}=\pi_{4}=0$ ) against the alternative (i.e. Ho: $\pi_{1} \neq 0 ; \pi_{2} \neq 0 ; \pi_{3} \neq 0 ; \pi_{4} \neq 0$ ). The calculated F-statistic in this procedure, however, has no standard distribution. In order to test for cointegration, two asymptotic critical value bounds are used. The lower bound assumes that all the regressors are I( 0 ) while the upper bound assumes that they are I(1). If the computed F-statistic lies above the upper bound, then the null hypothesis of no cointegration is rejected irrespective of whether the variable is $\mathrm{I}(0)$ or I(1). If the computed F-statistic falls below the lower bound critical value, then the null hypothesis cannot be rejected, thus supporting the absence of cointegration. However, if the computed value falls inside the critical value bound, then the cointegration test is inconclusive.

From the estimated UECM, the long run elasticities are the coefficients of the explanatory variables lagged one period (multiplied by a negative sign) divided by the coefficient of the dependent variable also lagged one period (see Bardsen, 1989). The short-run effects, on the other hand, are captured by the coefficients of the first differenced variables in Equation 2. Following the procedure in Pesaran and Pesaran (1997, p.305), we first estimate an OLS regression for the first differences part of Equation 2 and then test for the joint significance of the parameters of the lagged level variables. Table 4 presents the results of the ARDL-Bounds test based on Pesaran et al. (2001). 
Table 4: ARDL Bounds Test for Cointegration Analysis

\begin{tabular}{|c|c|c|}
\hline Computed F- Statistic: 5.998 & Lower & Upper \\
\hline Critical Bounds (5\%) & 3.79 & 4.85 \\
Critical Bounds (10\%) & 3.17 & 4.14 \\
\hline
\end{tabular}

Critical values are taken from Table C1(iii) of Pesaran et al (2001): Unrestricted intercept and no trend in the model.

The results of the Bounds test presented in Table 4 indicate that the computed F-statistic (5.998) exceeds the upper bound critical value (4.85) at the $5 \%$ level of significance. This indicates that there is a stable long-run relationship between the investment efficiency variable and its determinants, namely deposit rate, real exchange rate and foreign savings. Having confirmed the existence of a stable long-run relationship between the investment efficiency variable and its regressors, the next step is to derive the long run and short coefficients of the explanatory variables in the investment efficiency model by using the simplest UECM. Table 5 gives the results of the simplest UECM for the investment efficiency function - based on Henry's general to specific approach (1991).

Table 5: The Estimated UECM for the Investment Efficiency Function (IOCR)

\begin{tabular}{|l|c|l|}
\hline Variable & Coefficients & t-Statistics \\
\hline IOCRt-1 & 0.865594 & $-2.750597 * * *$ \\
\hline D-Pet-1 & -0.071086 & -1.611921 \\
\hline LExRatet-1 & 5.045910 & $3.887415^{* * *}$ \\
\hline Sf/Yt-1 & 0.115486 & 0.805114 \\
\hline$\Delta$ IOCRt-1 & 0.242506 & 1.096584 \\
\hline$\Delta$ IOCRt-2 & -0.371751 & $-2.220537^{* *}$ \\
\hline$\Delta$ D-Pet-1 & 0.142338 & $2.924683^{* * *}$ \\
\hline$\Delta$ LREXRt & -4.952755 & $-2.337337^{* *}$ \\
\hline$\Delta$ LREXRt-2 & -12.73880 & $-5.503400^{* * *}$ \\
\hline$\Delta$ SF/Yt-1 & -0.341520 & $-2.591374 * *$ \\
\hline$\Delta$ SF/Yt-2 & -0.200721 & -1.600564 \\
\hline Constant & -28.90053 & $-3.963651^{* * *}$ \\
\hline
\end{tabular}

Notes: $*, * *$ and $* * *$ denote significance at $10 \%, 5 \%$ and $1 \%$, respectively.

Dependent variable: $\triangle \mathrm{IOCRt}$

Sample: 1975-2006; Included observations: 29 after adjustments

R-squared: $\quad 0.867$

Adjusted R-squared: $\quad 0.781$

Durbin-Watson stat: $\quad 1.929$

F-statistic: 10.101 [Prob: 0.00002]

Ramsey RESET (1): 0.7169(0.409)

(2): $1.271(0.2595)$

The battery of tests performed for the above model shows the model generally conforms to the basic diagnostic tests. Specifically, the model does not suffer from serial correlation, nor is the model misspecified nor is the choice of functional form incorrect. The normality of the residuals is not rejected and, therefore, the reliability of the " $\mathrm{t}$ " values is ascertained. The residuals are also confirmed to be homoscedastic. The results presented in Table 5 show that in the long-run the investment efficiency in Tanzania is largely determined by the real exchange rate and lagged level of the investment efficiency. However, in the short-run nearly all the explanatory variables included in the investment efficiency model have a direct and significant affect on the level of investment efficiency in Tanzania. Specifically, the long-run coefficients of the investment efficiency function are 0.082 for interest rate, 5.829 for exchange rate and -0.133 for foreign savings.

The empirical results presented in Table 5 show that there is a robust short-run positive relationship between real deposit rate and investment efficiency in Tanzania. This is evidenced by the coefficient of the lagged deposit rate which is positive and statistically significant in the short-run model. However, in the long-run this relationship is statistically insignificant. The empirical results of this study show that the current financial reforms in Tanzania have a short-run positive and significant influence on the quality of investment. Other empirical results 
show that that foreign savings, real exchange rate depreciation and lagged value of investment efficiency have a negative effect on the efficiency of investment. This has been confirmed by the coefficients of the first difference of foreign savings, real exchange rate depreciation and lagged value of investment efficiency, which are all negative and statistically significant.

Since the stability of the investment efficiency function is vital in a study of this nature, it is also important to test whether the estimated investment efficiency equation has shifted over time. For this purpose, the CUSUM and CUSUM Square class of tests have been used. As can be seen from Figures 1 and 2, the CUSUM and CUSUM Square tests for stability indicate that the parameters are stable during the sample period.

Figure 1: Plots of CUSUM for UECM

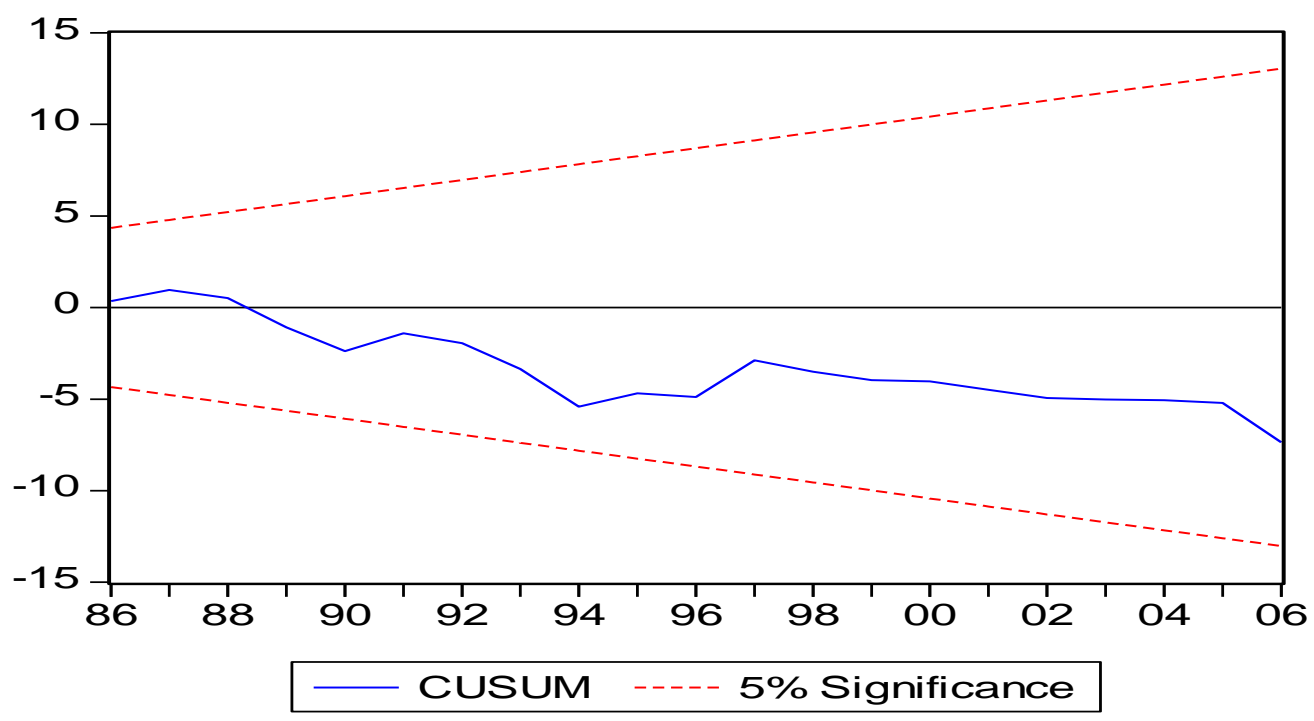

Figure 2: Plots of CUSUM of Squares for UECM

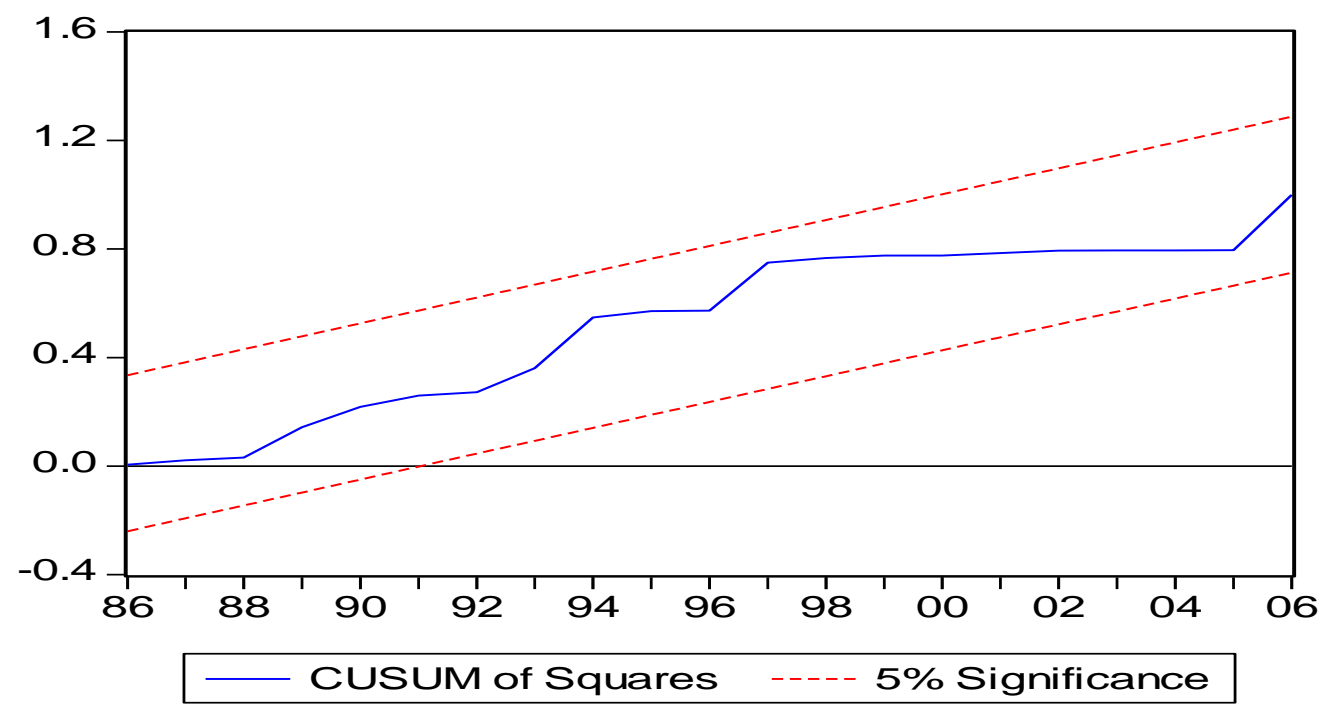




\section{CONCLUSION}

In this study, the impact of financial sector reforms on investment efficiency in Tanzania has been examined using the recently developed ARDL-Bounds test approach proposed by Pesaran et al. (2001). The empirical analysis of the investment efficiency (IOCR) function was based on the assumption that the average investment efficiency is monotonically related to the incremental output capital ratio (IOCR). Contrary to the results obtained in other previous studies, the empirical results of this study find a distinct positive relationship between real interest rate and investment efficiency in Tanzania in the short-run. The coefficient of the lagged real interest rate in the investment efficiency function is found to be positive and statistically significant as expected. This shows that interest rate reforms have a short-run positive influence on the quality of investment in Tanzania. It also implies that the current financial liberalisation taking place in the Tanzania has succeeded in transferring capital from projects with low returns to projects with high returns. This result is consistent with Odhiambo (2007), Jayaraman and Ward (2004) and Fry (1979). Other empirical results show that foreign savings and exchange rate depreciation reduce rather than increase the quality of investment in Tanzania.

\section{AUTHOR INFORMATION}

Prof. Nicholas M Odhiambo holds a PhD (Economics) degree from Stellenbosch University (South Africa) and a Masters degree in Economics from the University of Dar-es-salaam (Tanzania), both of which were sponsored by the African Economic Research Consortium (AERC). Prof Odhiambo's research profile is broad and rich, encompassing Monetary Economics, International Finance, Macroeconomic Modelling and General Economic and Policy Modelling. During the past seven years, Prof. Odhiambo has published more than 30 articles in both local and international journals. Professor Odhiambo is currently working as Full Professor in the Department of Economics at the University of South Africa (UNISA).

\section{REFERENCES}

1. Bardsen, G. (1989), "Estimation of Long-run Coefficients in Error-correction Models, Oxford Bulletin of Economics and Statistics 51: 345-50.

2. Bencivenga, V.R. and Smith, B.D.(1991), "Financial Intermediation and Endogenenous Growth" Review of Economic Studies 58: 195-209.

3. Capoglu, G. (1990), "The Effect of Financial Liberalisation on the Efficiency of the Turkish Financial System: 1980-88", A Paper Presented at the EEA Conference, Lisbon.

4. Caprio, et.al., (1994), Financial Reforms: Theory and Experience, New York, Cambridge University Press.

5. Cho, Y.J. (1988), “The Effect of Financial Liberalisation on the Efficiency of Credit Allocation”, Journal of Development Economics 29: 101-110.

6. De Gregorio, J. (1992), "Economic Growth in Latin America", Journal of Development Economics 39(1): 58-84.

7. De Gregorio, J. and Guidotti, P.(1995), “Financial Development and Economic Growth”. World Development 23(3): 433- 448.

8. Dickey, D and Fuller, W. (1979), "Distribution of the Estimators for Autoregressive Time Series with a Unit Root", Journal of American Statistical Association 74: 427-431.

9. Dickey, D and Fuller, W. (1981), "Likelihood Ratio Statistics for Autoregressive Time Series with a Unit Root", Econometrica 49: 057-72.

10. Elliot, G., Rothenberg, T. and Stock, J. (1996), "Efficient Test for An Autoregressive Unit Root, "Econometrica 64: 813 - 836.

11. Fry, M.J.(1979), "The Cost of Financial Repression in Turkey”, Savings and Development 3(2): 27-135.

12. Gelb, A., (1989), "Financial Policy, Growth and Efficiency", World Bank, Policy Planning and Research Working Paper, WPS 202.

13. Greenwood, J., and Jovanovic, B., (1990) "Financial Development, Growth, and the Distribution of Income", Journal of Political Economy 98 (October): 1076-1107.

14. Harris, J.R., Schiantarelli, F. and Siregar, M.G. (1992), "How Financial Liberalisation in Indonesia Affected Firms' Capital Structure and Investment Decisions”, World Bank Working Paper No.997, Washington D.C. 
15. Harris, J.R., Schiantarelli, F. and Siregar, M.G. (1992), “The Effect of Financial Liberalisation on Firm's Capital Structure and Investment Decisions: Evidence from a Panel of Indonesian Manufacturing Establishments 1981-1988”, World Bank Working Paper No.997, Washington D.C., World Bank (October).

16. Harris, R and Sollis, R. (2003), "Applied Time Series modelling and Forecasting”, Wiley, West Sussex.

17. Ikhide, Sylvanus, (1992), "Financial Deepening, Credit Availability and the Efficiency of Investment: Evidence from Selected African Countries", Development Research Paper Series, Research Paper No.2.

18. Jaramillo, F., Schiantarelli, F. and Weiss, A. (1992), "The Effect of Financial Liberalisation on the Allocation of Credit: Evidence from a Panel of Ecuadorian Firms", World Bank Working Paper, No. 1092, Washington, D.C., World Bank (February).

19. Jayaraman, T. and Ward, B. (2004), "Efficiency of Investment in Fiji”, The Empirical Economics letters 3(6): 321-332.

20. Khatkhate, Deena. R., (1988), “Assessing the Level of Interest Rates in Less Developed Countries”, World Development 19(1-2): 1-24.

21. McKinnon, R.I.(1973), "Money and Capital in Economic Development", The Brookings Institution, Washington D.C.

22. Morisset, Jacques, (1993), "Does Financial Liberalisation Really Improve Private Investment in Developing Countries" Journal of Development Economics 40 (February): 133-150:

23. Newey, W.K. and West, K.D (1987), “A Simple, Positive Semi-Definite, Heteroskedasticity and Autocorrelation Consistent Covariance Matrix", Econometrica 55: 703-8.

24. Ng, S. and Perron, P. (2001), "Lag Length Selection and the Construction of Unit Root Test with Good Size and Power", Econometrica 69: 1519-54.

25. Nyagetera, B.M.(1997), "Financial Repression in Tanzania, its Impact on Savings, Investment, Credit and Growth" Unpublished $\mathrm{PhD}$ thesis, University of Dar-es-salaam:

26. Odhiambo, N.M. (2003), "Interest rate Reforms and Investment Efficiency: The case of Two sub-Saharan African Countries", Savings and Development, Volume XXVII, Number 3, pp.317-335.

27. Odhiambo, NM (2008), "Interest Rate Reforms, Financial Deepening and Economic Growth in Kenya: An Empirical Investigation", Journal of Developing Areas 42(2) - Forthcoming.

28. Pesaran, M. and Shin, Y. and Smith, R. (2001), "Bounds Testing Approaches to the Analysis of level relationships", Journal of Applied Econometrics 16: 289-326.

29. Pesaran, M. and Shin, Y. (1999), “An Autoregressive Distributed Lag Modelling Approach to Cointegration Analysis, Chapter 11 in Econometrics and Economic Theory in the $20^{\text {th }}$ Century: The Ragnar Frisch Centennial Symposium, Strom S(ed). Cambridge University Press: Cambridge

30. Phillips, P.C.B. and Perron, P., "Testing for a Unit root in Time Series regression”, Biometrika, 1988, Vol. 75, pp. 335-346.

31. Renelt, D. and Levine, R. (1992), "A Sensitivity Analysis of Cross-Country Growth Regressions" American Economic Review 82 (4): 942-963.

32. Saint-Paul, Gilles, (1992), "Technological Dualism, Incomplete Financial Markets, and Economic Development", Journal of International Trade and Economic Development 1 (June): 13-26.

33. Siregar, Miranda, (1992), "Financial Liberalisation, Investment, and Debt Allocation", Ph.D. Dissertation, Boston University.

34. Thornton, J. (1990), “The Demand for Money in India: A Test of McKinnon's Complementarity Hypothesis", Savings and Development 14 (2): 153-159.

35. Williamson, J., and Mohar, M., (1998), “A survey of Financial Liberalisation” Essays in International Finance, Princeton University, No. 211 (November).

36. Ziorklui, S.Q. (2001), "Capital market Development and Growth in sub-Saharan Africa: The case of Tanzania, African Economic Policy Discussion Paper No. 79, Washington DC. 